\title{
Lorentz Dietrichson (1834-1917) and the Beginnings of Systematic Studies on Iconography
}

\author{
Per Jonas Nordhagen
}

In 1875, Lorentz. Dietrichson was called to a chair in the history of art in Kristiania (Oslo), the first professorship established for this discipline in Norway. With boundless energy he laid the groundwork for a distinguished tradition of academic studies of art in this country, and worked for the establishment of organizations and museums for the advancement of artistic culture. He wrote the first large survey on the bistory of Norwegian art and published pioneering books on Norwegian medieval architecture and ornament. Foremost among the latter ranks his 1892 monograph on the Norwegian stave churches, which with its solid documentation of the surviving specimens of this unique architectural category, supplemented by the available information on those which were lost over the centuries, is still regarded as the fundament for all studies on the matter. Dietrichson was a prolific writer of popular articles and essays, and as a lecturer he became famous for his precious language and for his exquisite and 'soulful' interpretations of art works. However, the easiness with which enlightened judgements on art flowed from his lips and pen should not mislead us to doubt the seriousness be brought to his scholarly efforts or his involvement in the improvement of the instruments of research. He and the scholars from his generation moved the art of describing art objects towards a higher level of precision. Late in life he witnessed the rise of the new tool, photography, as an auxiliary in the study of images and their meaning. It brought comparison, the methodical key to advanced iconographic study, to new heights of exactness. Most of Dietrichson's research, however, took place in the period before this means became fully available. His never-ending hunt for his material, which he sought in uncharted collections spread over many countries, and the problems he met in providing illustrations of it, is the theme of this essay. These are forgotten pages in the annals of Norwegian archaeological research.

To start this survey with Dietrichson's work on classical portraiture, will seem, for an art historian, to attack the matter from the wrong end. ${ }^{1}$ Still, it is from his descriptions of the toil suffered in the collecting of the objects pertaining to Antinous that we get the best idea of what it took to bring together facts and pictures on an artistic matter

\footnotetext{
1 The text is an expanded version of a paper on Lorentz Dietrichson's place in the historiography of motif-investigation, see Nordhagen 1981.
} 


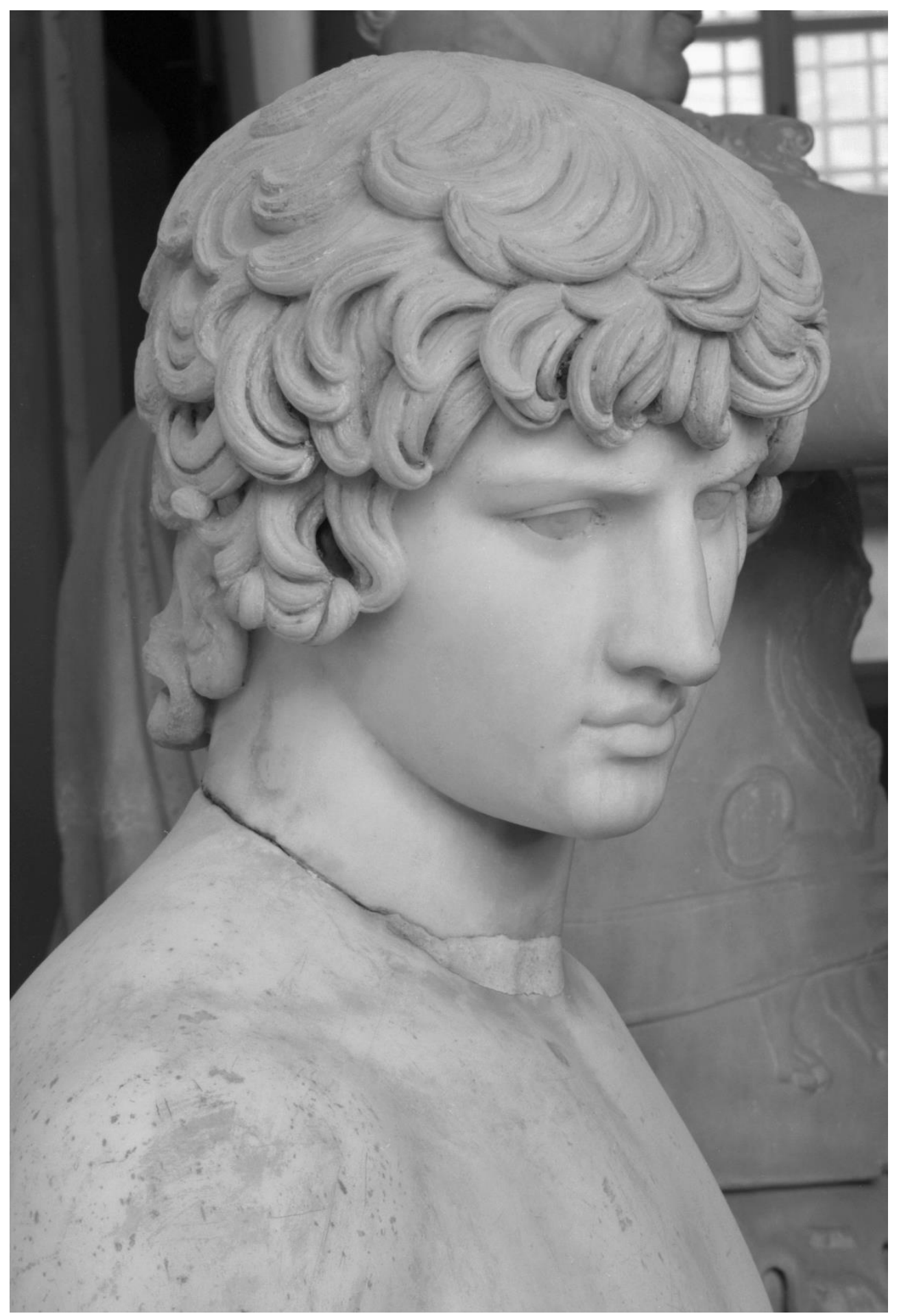

Fig. 1 Antinous, detail. From the Farnese Collection. Museo Narionale, Naples, inv. 6030. Photo: D-D AI-ROM-83.1894. 
in the days before the formation of large photographic archives and specialized institutes of research. With Antinoos. Eine kunstarchäologische Untersuchung (1884) Dietrichson ventured, not without trepidation, into the field of classical archaeology as he states in the book's opening pages. ${ }^{2}$ To bring together a census ofall extant portraits of Antinous, the youthful companion of Hadrian, the Roman emperor, was the aim of his efforts, but also to assemble all other archaeological documents connected with this intriguing figure. Work on a general 'Iconography of the Roman Emperors' was in the coming in the latter half of the nineteenth century, when the task of cataloguing the contents of the large European collections of classical art began under new and heightened principles of scholarly acumen. Dietrichson's ambition was to publish a monograph, researched according to radical new parameters, on the portraits of Hadrian's young favourite, whose life and destiny held a growing fascination for the European intellectual elite of the late Romanticist Era.

Dietrichson's choice of subject, in fact, was inspired by a literary-poetic vogue, steeped in period sentimentality, to which he and many of his contemporaries succumbed. It regarded the myth-laden story of the handsome young Bithynian who accompanied Hadrian on his many travels and who died under mysterious circumstances in Egypt during a voyage on the Nile. According to Dietrichson's own words, it was the beguiling enigma which shrouded the life and death of Antinous that inspired him to take up the work. In his introductory chapter he affirms, in flowering prose, how not only the story in itself but, above all, the veil of sadness which clings to all portraits of Antinous, had attracted him. The air of melancholy imprinted upon this noble head was part of a taunting riddle (Fig. 1). Yet there is more to this picture. Like many well-educated people of his time from the higher strata of society, Dietrichson felt an urge to come to the defence of the beautiful youth and to help in dispelling the 'ugly' rumours, rampant already in Antiquity, about the unnatural relationship that had sprung up between the boy and the emperor. This liason, it is true, has continued to occupy the imagination of both authors and historians up to the present day. ${ }^{3}$ What became important to the Late Victorians, was to have History and its tales 'cleansed' of its impurities and made congruent with the prim rules of conduct now imposed upon the ruling classes. The story of Antinous and the emperor thus had to be rewritten into a narrative in which the two were brought together not by physical passion but by their lofty common interests. What united them, one insisted, was their love of philosophy, above all Platonism, and of the Cult of Beauty, but also their shared attraction for the rites of certain Hellenic mystery religions. Dietrichson refers to the Swedish historian and author Victor Rydberg, who in an essay from the 1870s had gone a long way in rehabilitating the Antinous-Hadrian constellation, in which he saw an elevated soul-relationship between two people come from the highest

\footnotetext{
2 Dietrichson 1884.

3 Yourscenar 1951. Lambert 1984/1997; in his work Lambert pays tribute to Dietrichson, 'the industrious Norwegian professor' who was the very first to give a precise summary, with the relevant archaeological material included, of the Antinous-Hadrian story.
} 
levels of culture and learning. Rydberg's version, underwritten by Dietrichson in engaged passages, is one which became palatable to a society which prided itself of its high moral standards.

After this outpour of rather naive ramblings on all-male relationships in Antiquity, Dietrichson's book comes to a turning point. From now on it is scrupulously factual and scholarly. The florid style of its first chapters has evaporated, and the author pursues the amassment of archaeological facts in a language free of unnecessary pretensions or ornament, to give descriptions that are terse and incisive and aimed at giving the essential. The ideals of empirical perfectionism which are perceptible here no doubt sprang from German archaeological scholarship, a discipline with which Dietrichson had become acquainted during his study years at the European universities, and which in the last part of the nineteenth century had become the leading school in the charting of the relicts from the past. It is important to note that this new way of objective description came to influence not only Dietrichson's books on architecture, in particular his De Norske Stavkirker, but also his chapters on Late Antique and Early Christian iconography.

But first some more words on the Antinous project. The second part of his book Die Antinoosmonumente tabulates a total of 137 sculptures representing Antinous, including some debatable and some which are spoken of only in the documents. Further, he lists a long series of incised gems and cameos with the same motif, and about 130 different coins which bear Antinous' portrait. Finally, he adds all the sources then available on the temples dedicated by the emperor to his companion and the inscriptions put up in his honour, all rendered in their original languages. Among these is even illustrated and transcribed the hieroglyphic inscription on Antinous' obelisk in Rome. The thoroughness with which this work of compilation is carried through is astounding, as is Dietrichson's description of the itinerary he followed to achieve his goal:

Eine genaue Untersuchung der Antinooswerke war die Hauptaufgabe der Studiereise, welche ich - zum Teil mit staatliche Unterstïtrung - in den Jahren 1880 und1881 unternabm. Ich untersuchte auf diese Reise die Antinoosbilder in Paris, Berlin, Dresden, München, Turin, Venedig, Rom und Neapel, fand auf derselben ausserdem die beiden Büsten in Patras, die soweit mir bekannt, hier zum ersten Mal in der Literatur besprochen werden, berichtichte ferner aufs neue jene Statue in Eleusis, welche ich bereits 1870 in dortigen Museum gesehen zu haben meinte, und ging entlich nach Ägypten, wo ich im Museum von Bulak die Inschrift auf der Basis einer (verschwundenen) Statue aus Antinoë abscbrieb, und den Nil bis Antinoë befubr... Schon früber hatte ich andere Städte in welchen sich Antinoosbilder befinden, aufgesucht, St. Petersburg, Stockholm, London... ${ }^{4}$

\footnotetext{
${ }^{4}$ Dietrichson 1884,8.
} 


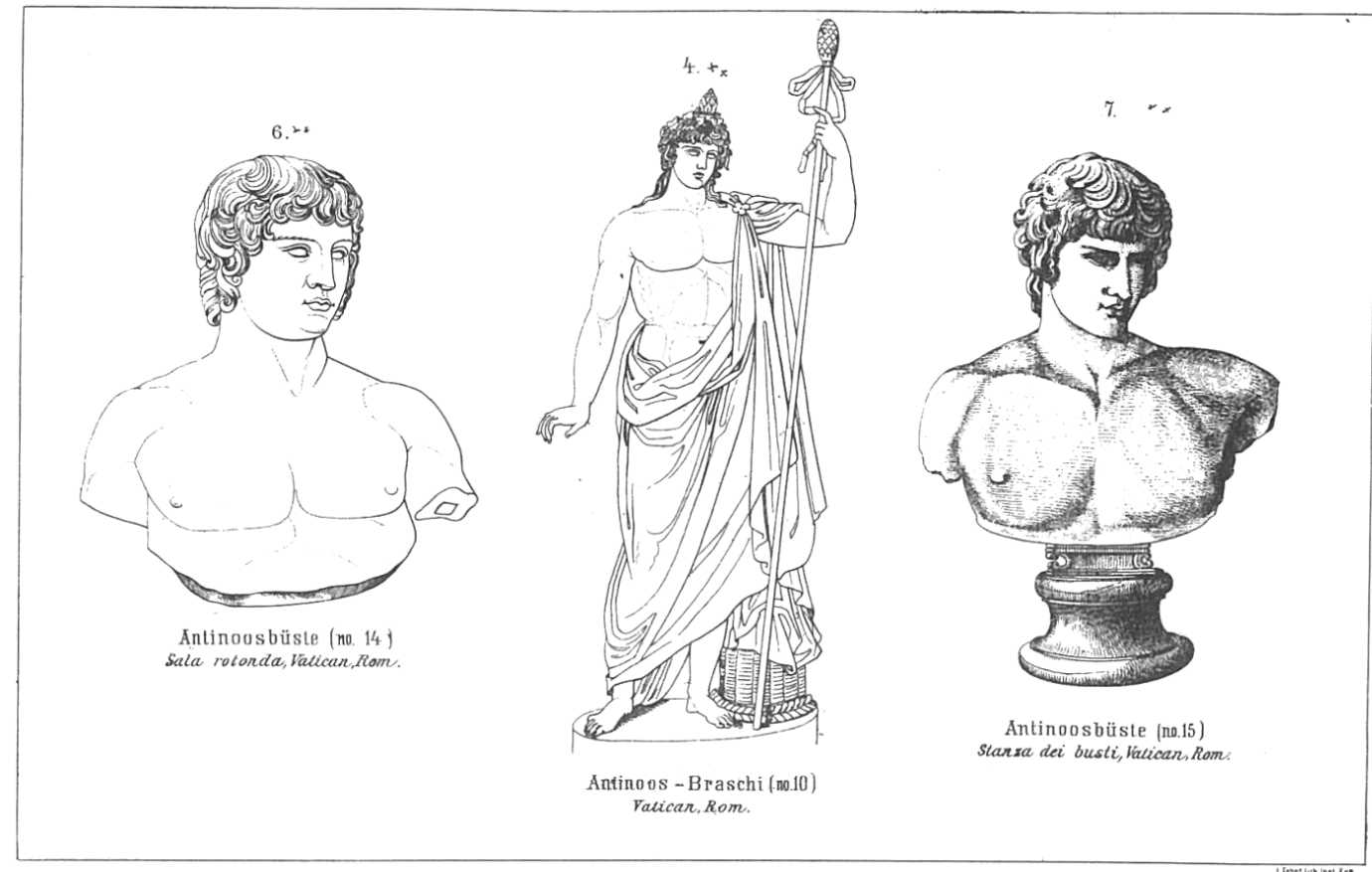

Fig. 2 Portraits of Antinous in the Vatican Museums. Works in marble. From Dietrichson 1884, Pl. II.

Due to the determination with which he drove his undertaking, he was able to study, 'an Ort und Stelle', eighty-one of the sculptures he presented in his book and to describe them in detail. The iconographic minutiae harvested under this itinerant scrutiny, like the garments and attributes with which Antinous is represented in his various appearances, are rigorously classified. This deep knowledge of the material made it possible for Dietrichson, in the accompanying commentary, to produce the first comprehensive survey of the many acts of apotheosis which Hadrian showered upon his dead friend. Of these, he pointed to the identification of the boy with the gods Apollo, Bacchus-Dionysos, Hermes and the Egyptian Death-god Osiris as the most significant ones; his observations added new perspectives to the study of the religious syncretism of the Roman imperial centuries. But also facts concerning the material the sculptures were made of, are closely registered, features that are important to the questions regarding the authenticity of each object: '...lunensicher Marmor, roter ägyptischer Granit' etc. Nor are the restorations or destructions to the pieces ignored: 'Restaurirt ist der Zeigefinger der rechten Hand, fast die ganze Guirlande, sowie die Partie um die linke Hand...'

These advances in accuracy moved the study on Antinous to the first rank in Roman iconographical studies. C.W. Clairmont's Die Bildnisse des Antinous from 1966, published by The Swiss Archaeological Institute in Rome, puts Dietrichson's work on the list of publications most frequently referred to in the text; it is given rank as the 


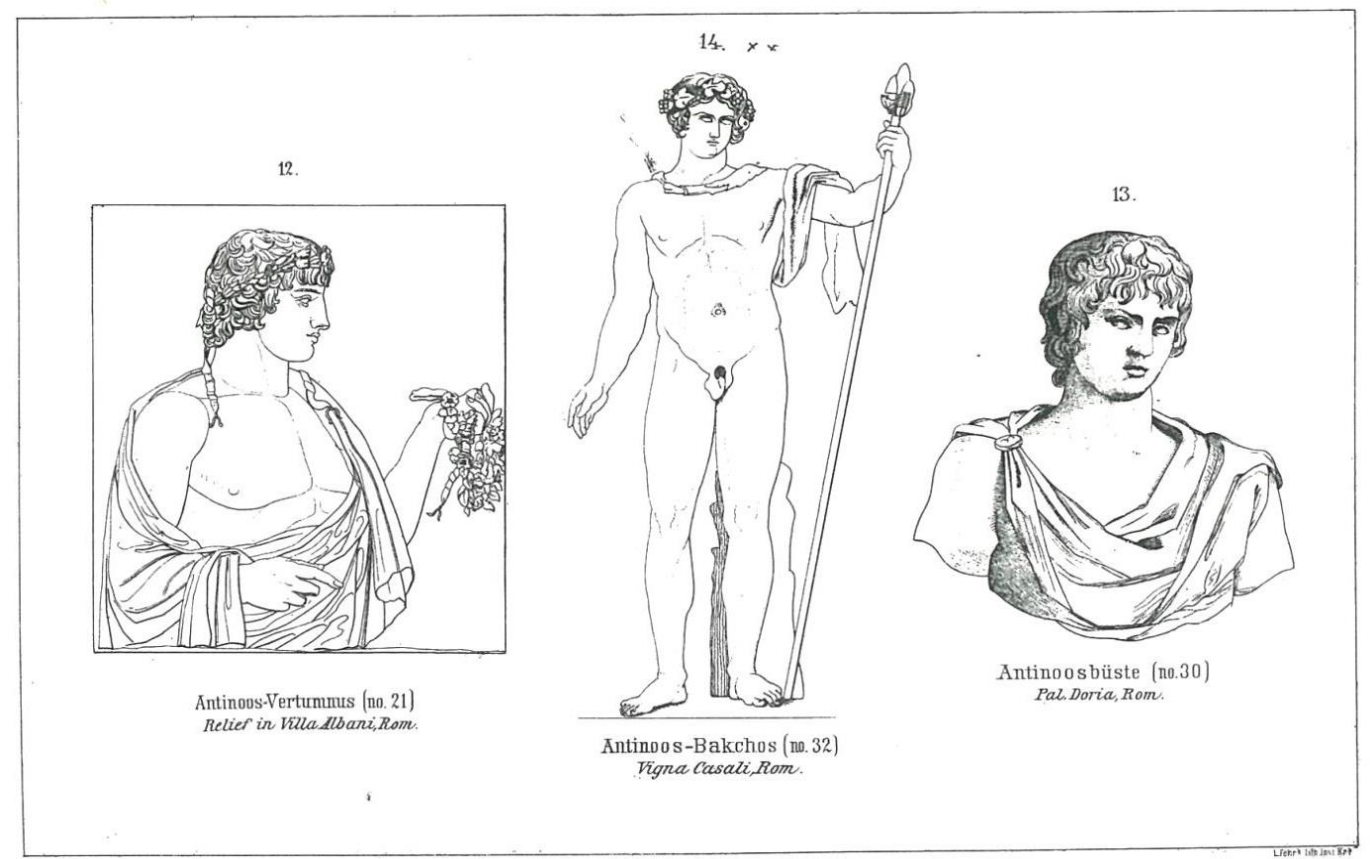

Fig. 3 Portraits of Antinous in other Roman collections. Works in marble. From Dietrichson 1884, Pl. V. II.

first serious and scholarly investigation on the matter. ${ }^{5}$ The illustrations, lithographed copies of drawings made by his wife, the artist Mathilde Dietrichson, who followed him on his travels, offered the earliest near-complete display of these suggestive products of Hadrianic Classicism (Figs. 2-3).

Dietrichson's Christusbilledet. Studier over den typiske Christusfremstillings Oprindelse, Udvikling og Oplosning ('The Image of Christ. Studies on the typical Image of Christ, its Origin, Development and Dissolution') was published in Norwegian in 1880, four years before his book on Antinous. ${ }^{6}$ The assembling of it was almost as gruelling as that which preceded Antinoos. In his preface Dietrichson states that he pursued the collecting of the relative facts for more than a decade:

When the notes for this material had followed me from Syracuse in Sicily to the Cathedral at Trondheim, from Bayeux to Ephesus and from St. Petersburg to Athens for 12 consecutive years, and I had reworked the material for nearly a year in the Königliche Hofund Staatsbibliothek at Munich, which is splendidly equipped for such a purpose, I now feel an urge to present it to the public.

\footnotetext{
${ }^{5}$ Clairmont 1966. Dietrichson's catalogue is also referred to in the list of Antinous sculpture in Lambert 1984/1997.

${ }^{6}$ Dietrichson 1880.
} 


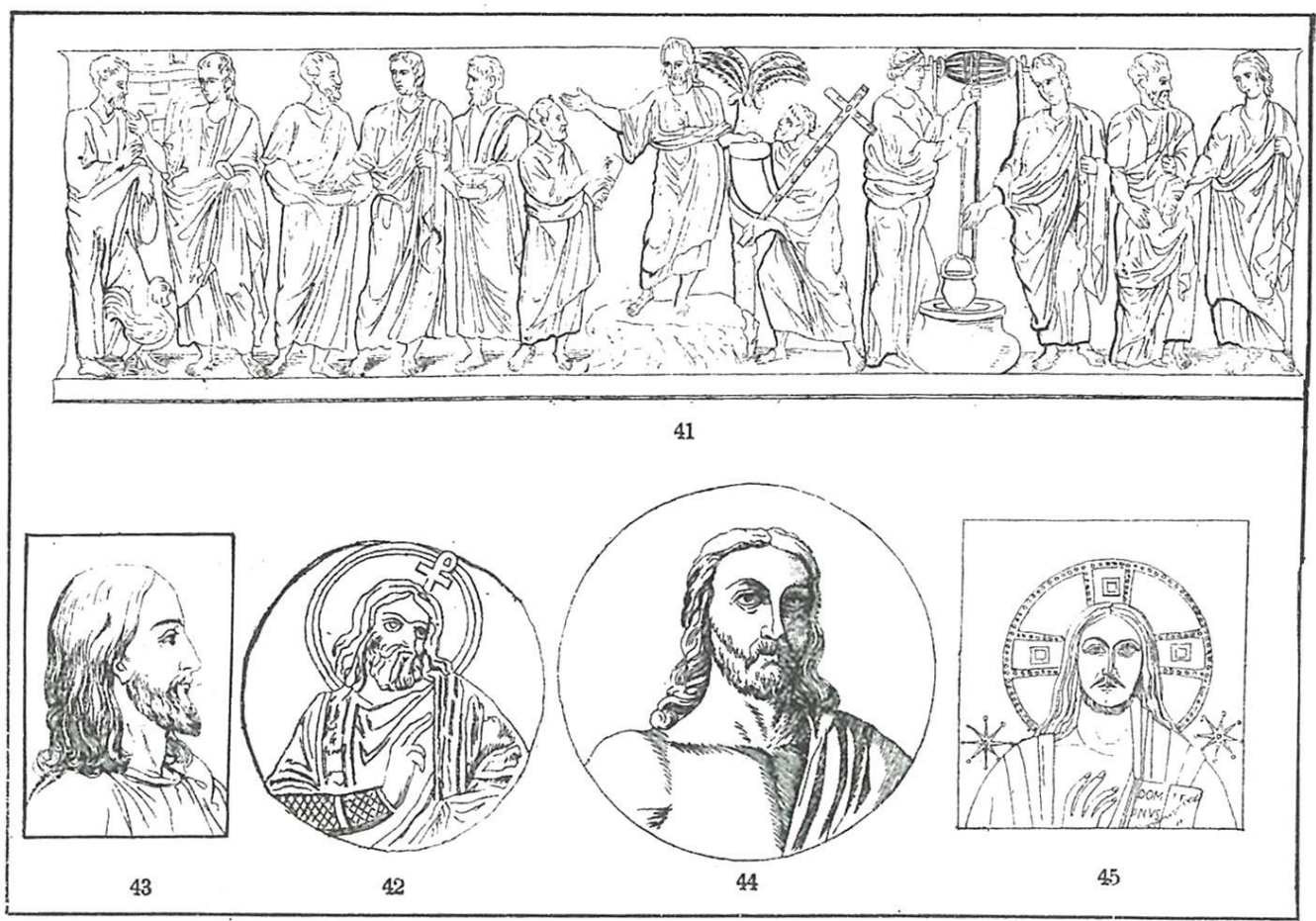

Fig. 4 'The earliest portraits of Christ'. From Dietrichson 1880, Pl. VII.

According to information culled from his memoirs Svundne Tider, the studies in Munich took place in the years 1876-1877.

Christusbilledet is more all-inclusive and encyclopedic than the study on Antinous, and also less sharply scholarly-critical. It betrays Dietrichson's propensity for popular divulgation and his desire to disseminate learning and good taste among his countrymen. In bourgeois high culture of the closing decades of the nineteenth century, there was a marked interest in religious images and their meaning. Dietrichson's survey, which spans the period from Late Antiquity to his own days, reflects a work of compilation that is truly impressive, and he draws a host of littleknown or overlooked objects out of obscurity and generates new knowledge about them. In its larger lines, however, the book is built as much on secondary literature as on his own examination of the relevant material; its attempt at synthesis is its greatest merit. Even taking its inadequate illustrations, line drawings of little distinction (Fig. 4), into consideration, the book, on the strength of its accumulation and classifying of countless types and schools, will remain a significant step in the improvement of method. A German translation of the book was planned but did never realize. Still,

\footnotetext{
${ }^{7}$ Dietrichson 1913.
} 
Christusbilledet is referred to as a major work in Meyers Konversationslexicon, the influential German encyclopaedia, under the article Christusbild in its 1897 edition.

In the pages he devoted to the initial phase of the story, Dietrichson implanted new ideas. He was well ahead of his time when with learned arguments he declared the earliest types of Christ to be derivations of pagan prototypes. In the probing into this matter, he exhibited a scholarly zeal similar to what led him on his relentlessly hunting down of the widely scattered material pertinent to Antinous. In presenting his thesis he acknowledged his debt to another Nordic sage, the Danish poly-historian, university professor and Protestant bishop of Sjælland, Friedrich C.C.H. Münter and his book on Early Christian imagery from $1825 .{ }^{8}$ With his treatise Münter was to crush, with weighty arguments, the myths which told of an Urbild of Christ said to have been made in the Saviour's own lifetime and to be the archetype from which all later pictures of Him derived. ${ }^{9}$ On the basis of his profound studies in Italy on Roman and Early Christian monuments in the 1780s, at a time when classical archaeology was in its earliest stage, Münter would stress the similarity which existed between certain portraits of the ancient gods and the types of the Saviour introduced in the first Christian centuries. Likewise, Italian savants had begun to doubt that the catacombs, with their rich display of pictures of Christ, had originated as early as in the time of the disciples. One saw now that they were taken in use considerably later and that there was, in fact, a distinct time gap between the earliest days of Christianity and the time when the first portraits of the Redeemer made their appearance. The overriding question, then, regarded what models one drew upon when His features were to be reconstructed and His physiognomy brought to life. This was the time when pious exegesis slowly lost its grip and was replaced by disinterested inquiry into the processes and events that shaped religious imagery. ${ }^{10}$

Dietrichson adopted several of Münter's main deductions. In a first group he placed the youthful and beardless type of Christ seen on many sarcophagi (Fig. 5); this he labelled 'The Apollo-like image of Christ, or the origin of the beardless symbolical type'. His second group embraced the full-bearded Christ who appears on both sarcophagi and in painting; this he called 'The Zeus-like Christ image, or the origin of the Salvator type and the Byzantine Pantokrator-type'. As to this category, he was more insistent than the Dane in ascribing it to a direct influence from the images of Jupiter-Zeus, the ruler of the pagan Pantheon, and singled out several

\footnotetext{
${ }^{8}$ Münter 1825.

${ }^{9}$ Nordhagen 1995.

10 One of Münter's radical theses, unheard of at his time, regarded the most holy of Christian motifs, the group of the Virgin and the Child. With his insight into Egyptian antiquities he suggested, without irreverence, that it had been adopted from Egyptian representations of the goddess Isis with the boy Horus on her lap. See Münter 1825 II, 27. Modern research confirms his idea.
} 


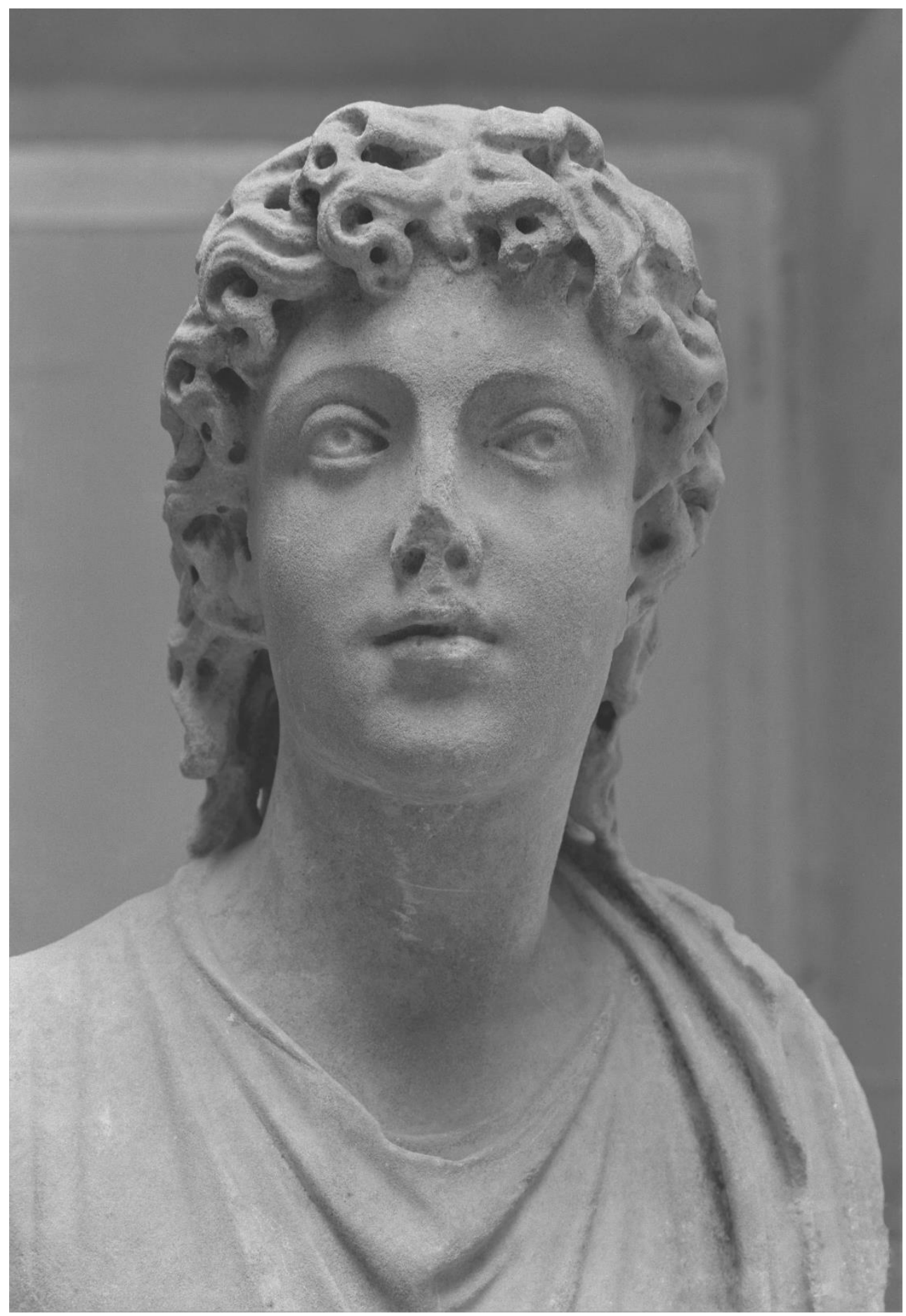

Fig. 5 'Christ-Apollo', possibly from Civita Lavinia, c. 360 AD. Statuette of Christ in Museo Nazionale Romano, inv. 61565. Photo: D-DAI-ROM-31.1412. 
possible prototypes. Support for his thesis he found in his reading - not free of speculation - of the syncretistic texts which circulated in the early Christian era.

Dietrichson's third group is labelled 'The Dionysos-like Christ image', and builds on another of Münter's observations, which by re-introducing it he brought to the attention of contemporary scholarship. The reactions to Dietrichson's theses, were, as expected, mostly negative. For their time they were still too radical and unacceptably anti-dogmatic. The great German scholar Ferdinand Piper, another of the founding fathers of systematic studies of Christian iconography, had downright excluded that any such metamorphosis could have taken place. Yet in his seminal studies on Early Christian art, the same scholar was not blind to the fact that many central pagan symbols and motifs had found their way into Christian cult practice. ${ }^{11}$ The Dietrichson-Münter paradigm, however, had to wait for another generation before it became generally acceptable.

Research in the twentieth century added weight to their theses, but brought important modifications. Stock was now taken of all Early Christian visual remains whether in situ, on view in collections or hidden in museum store rooms, to produce a wholly new picture of the processes of motif-creation which unfolded in the first Christian era. Rumination on the portraits of Christ and their possible antecedents never ceased, but was for a time mostly confined to articles presenting single objects or were part of the discussions of detail in the larger monument publications. Gradually, however, results distilled from these primary sources of learning found their way into modern surveys and college textbooks. In André Grabar's magisterial summing-up, Christian iconography. A study of its origins, published in 1968, the making of the image of Christ was a central theme. Grabar confronted without hesitation heads of Christ from the fourth century with classical representations of the bearded Jupiter, one of which the so-called Zeus from Otricoli, and pointed persuasively to the many features which link them. But as he explicitly added, Jupiter was but one among the gods of pagan mythology who wore a beard; two of the other principal gods, Neptune and Pluto, were also bearded. Then there was also Asclepius, the God of Healing, who with his mild look and long locks of hair is another close contender. ${ }^{12}$

Learned discussions have added further aspects. Friedrich Gerke, whose book on the early iconography of Christ, Christus in der spätantiken Plastik (1941) predated Grabar's synthesis, brought new arguments: the full-bearded, bare-chested Christ who appears in several images, was not grafted on Jupiter, but is drawn from depictions of pagan philosophers. Gerke's main example is the figure of Christ on the famous polychrome sarcophagus fragment in Museo Nazionale in Rome (Fig. o).$^{13}$ The origins

\footnotetext{
11 Piper 1847 [1972].

12 'Der menschenfreundliche' Asclepius was also Münter's foremost choice; Münter 1830, II, 7.

13 Gerke 1941, 12ff. Dinkler 1979 returns to the figure of Christ on the Museo Nazionale Romano fragment and offers new arguments for its possible derivation from the Zeus-Asclepius type.
} 


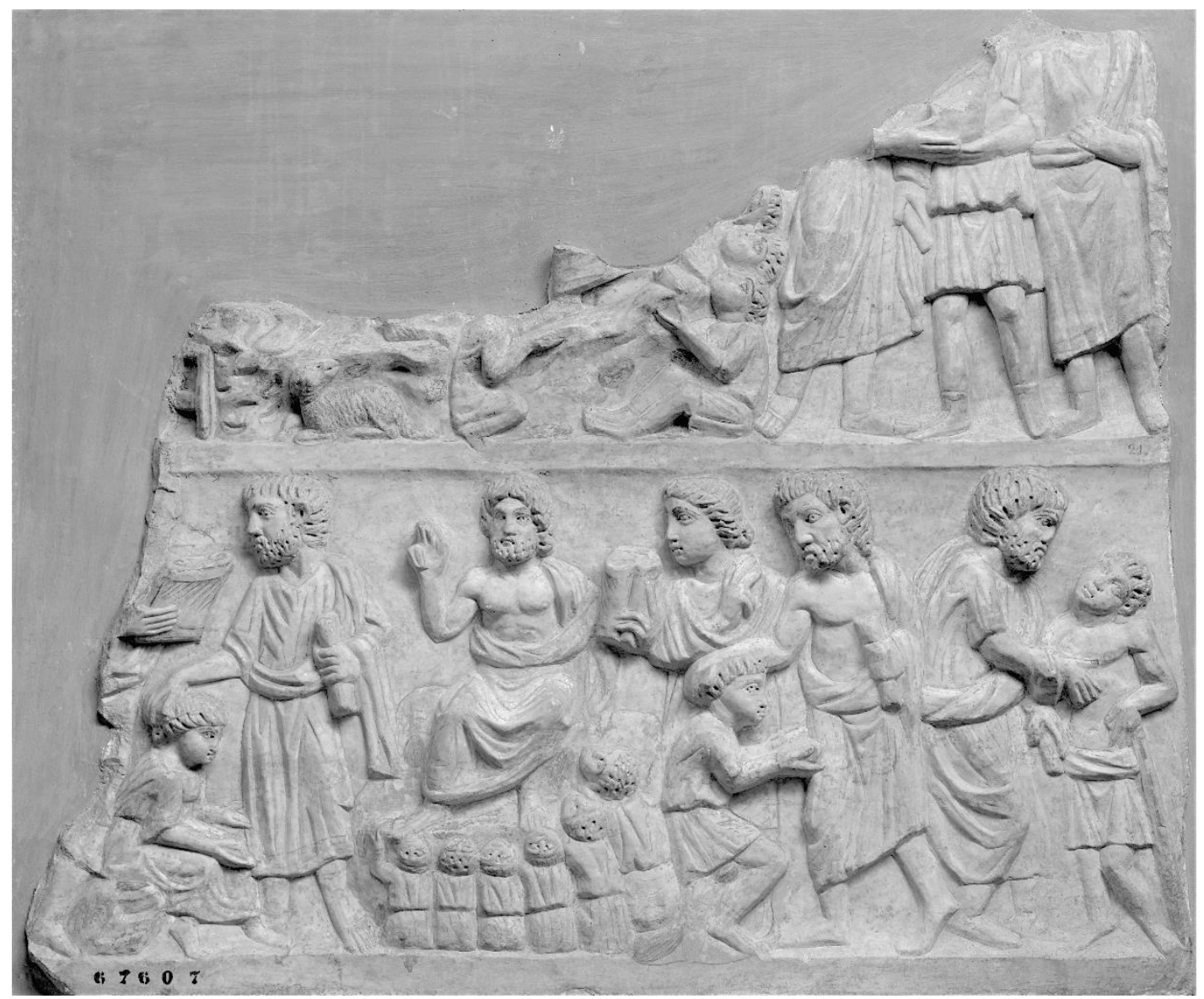

Fig. 6a Christ Philosopher with his pupils sitting at his feet. 'The coloured sarcophagus fragment', c. 300 AD. Rome, Museo Nazionale Romano, inv. 67607. Photo: D-DAI-ROM-57.73.

of the portrait of Christ is a problem for which a consensus, even in the long run, is hard or even impossible to obtain; the idea, however, that the early types of Christ borrow their countenances from pagan gods of the waning Roman world, has kept its weight and attraction. ${ }^{14}$

In 1917, the American art historian Charles Rufus Morey laid the foundations for what was to become The Princeton Index of Christian Art (now The Index of Christian $A r t)$, a central photographic archive at the disposal for motif research. ${ }^{15}$ At the time when Morey launched his program, almost forty years had elapsed since the publication of Dietrichson's Christusbilledet, a work which had the pretensions of

14 Jensen 2000, chapter 'Portraits of the Incarnate God', 94-129, esp. 98-100, 119-120; with bibliography. H. P. L'Orange (1903-1983), professor of Classical Archaeology at the University of Oslo, is among those who have contributed significantly to the discussion on this problem; H. P.

L'Orange 1953/1982.

15 Marter 2011; Woodruff 1942. 


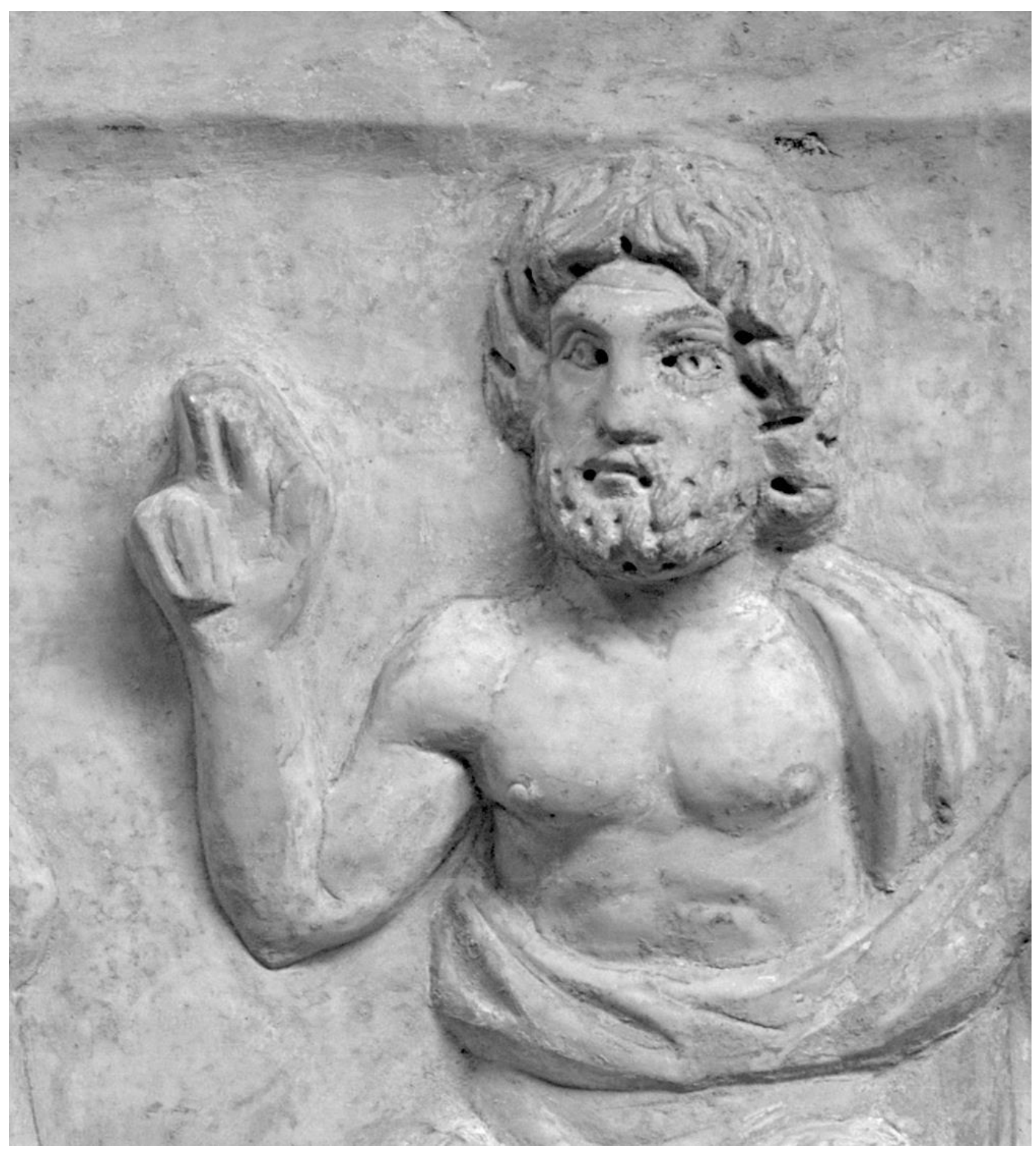

Fig. 6b Detail from fig. 6a with the 'Bearded Christ', the 'Philosopher type', c. 300 AD. Rome, Museo Nazionale Romano, inv. 67607. Photo: D-DAI-ROM-57.73.

bringing together widely scattered iconographic specimens. One might say that with the Index the torch was passed on, to crown the attempts, undertaken in the second half of the nineteenth century, to make available to scholarship the wealth of Christian imagery. Dietrichson's project was but one of these efforts aimed at method improvement. The Index, which I have had the privilege to use, first at its copy in the Vatican Library, later at another copy deposited at The Dumbarton Oaks Library in Washington DC, and now, finally, on the Internet, is an exceptional tool, and it has 
played a decisive part in my own research. Today it is but one of several such kinds of research machinery. It is the fulfilment of an idea which grew slowly and took a long time in the coming, but which brought us an instrument that is exemplary empiricist, practical and vanguard.

Per Jonas Nordhagen

Professor emeritus

University of Bergen

E-mail: pjnordhagen@gmail.com 


\section{Bibliography}

Clairmont, C.W. 1966: Die Bildnisse des Antinous, Rome.

Dietrichson, L. 1880: Christusbilledet. Studier over den typiske Christusfremstillings Oprindelse, Udvikling og Oplosning, Copenhagen.

Dietrichson, L. 1884: Antinoos. Eine kunstarchäologische Untersuchung, in Universitätsprogramm für das 1ste Semester, Kristiania.

Dietrichson, L. 1913: Svundne Tider I, Kristiania.

Dinkler, E. 1979: 'Ikonographische Beobachtungen zum Christustyp der polychromen

Fragmente des Museo Nazionale Romano', Gesta 18, 77-87.

Gerke, F. 1941: Christus in der spätantiken Plastik, Berlin.

Grabar, A. 1968: Christian Iconography. A Study of its Origins, Princeton.

Marter, J. (ed.) 2011: 'Charles Rufus Morey', The Grove Encyclopedia of American Art, Oxford.

Jensen, R.M. 2000: Understanding Early Christian Art, London \& New York.

Lambert, B. 1984 [1997]: Beloved and God. The Story of Hadrian and Antinous, London.

L'Orange, H.P. 1953 [1982]: Studies in the Iconography of Cosmic Kingship in the Ancient World, Oslo [reprint New Rochelle].

Münter, F.C.C.H. 1825: Sinnbilder und Kunstvorstellungen der alten Christen I-II, Altona.

Nordhagen, P.J. 1981: 'Lorentz Dietrichsons ikonografiske studier', Kunst og Kultur 64, 191-203.

Nordhagen, P.J. 1995: 'Frederik Münter (1761-1830) and Early Christian Iconography'. In

Knapas, M.T. \& Å. Ringbom (eds), Icon to cartoon. A Tribute to Sixten Ringbom (Konsthistoriska Studier) 16, Helsinki, 237-246.

Piper, F. 1847 [1972]. Mythologie und Symbolik der christlichen Kunst I, Weimar [reprint Osnabrück].

Woodruff, H. 1942: The Index of Christian Art: A Handbook, Princeton.

Yourcenar, M. 1951: Mémoires d'Hadrien, Paris. 